\title{
Manganese carbonyl complexes of 2,5-dimethylbismolyl. The crystal and molecular structure of ( $\eta^{1}$-2,5-dimethylbismolyl) manganese pentacarbonyl
}

\author{
Arthur J. Ashe, III, Jeff W. Kampf and Dhananjay B. Puranik \\ Department of Chemistn, The University of Michigan, Ann Arbor, MI 48109-1055 (USA)
}

(Received June 29, 1992; in revised form August 24, 1992)

\begin{abstract}
( $\eta$ - ${ }^{1}-2,5$-Dimethylbismolyl)manganese pentacarbonyl (8) has been obtained from the reaction of 1-phenyl-2,5-dimethylbismole with lithium followed by $\mathrm{BrMn}(\mathrm{CO})_{5}$. Heating 8 to its melting point causes the loss of $\mathrm{CO}$ to produce $\left(\eta^{5}-2,5\right.$-dimethylbismolyl)manganese tricarbonyl. Compound 8 crystallizes in the monoclinic crystal system, space group $P 2_{1}$ (No. 4) with $a=6.838(2) \AA, b=6.424(1) \AA$, $c=15.787(4) \AA, \beta=95.68(2)^{\circ}, V=690.1(2) \AA^{3}$ and $Z=2$. A full structure has been determined and is compared with those of analogous compounds.
\end{abstract}

\section{Introduction}

Heterocyclopentadienides of the Group 15 elements (1-5) are versatile ligands towards transition metals [1]. $\mathrm{Mn}(\mathrm{CO})_{5}$-complexes (6), in which the heteroatom is $\eta^{1}$-coordinated, are known for tetraphenyl derivatives of 2,3 and 4 [2]. Similarly $\mathrm{Mn}(\mathrm{CO})_{3}$-complexes (the heterocymantrenes) (7) have been reported for derivatives of 1 [3], 2 [4], 3 [5] and 4 [6]. The absence of analogous $d_{6}-\mathrm{Mn}^{\mathrm{I}}$ complexes of bismolyl (5) makes their synthesis desirable in order to complete the series.

We now wish to report on the preparation of $\left(\eta^{1}-\right.$ 2,5-dimethylbismolyl)Mn(CO) $)_{5}(8)$ and $\left(\eta^{5}\right.$-2,5-dimethylbismolyl) $\mathrm{Mn}(\mathrm{CO})_{3}(9)$. Since there are no prior structural data for $\left(\eta^{1} \text {-heterolyl)Mn(CO) }\right)_{5}$ complexes and relatively few structural data on organobismuth transi-

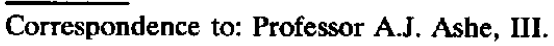

tion metal complexes [7], we have obtained a crystal structure for $\mathbf{8}$.<smiles>C[Te]1C=CC=C1</smiles>

$1, \mathrm{E}=\mathrm{N}$

2, $E=P$

3, $\mathrm{E}=\mathrm{As}$

$4, E=S b$

5, $\mathrm{E}=\mathrm{Bi}$

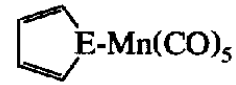

(6)<smiles>CC(C)(C)Oc1ccccc1</smiles>

(7)<smiles>CC1=CCC(C)[Bi]1C(=O)O</smiles>

(8)<smiles>Cc1ccc(C(C)(C)C)c(Br)c1</smiles>

(9)

\section{Results and discussion}

The reaction of 1-phenyl-2,5-dimethylbismole (10) [8] with lithium in $\mathrm{THF}$ at $25^{\circ} \mathrm{C}$ gave a green-brown solution of (2,5-dimethylbismolyl)lithium and phenyllithium, which on sequential reaction with $\mathrm{NH}_{3}$ to remove the phenyllithium, followed by $\operatorname{BrMn}(\mathrm{CO})_{5}$, 
TABLE 1. Structure determination summary of $8^{\text {a }}$

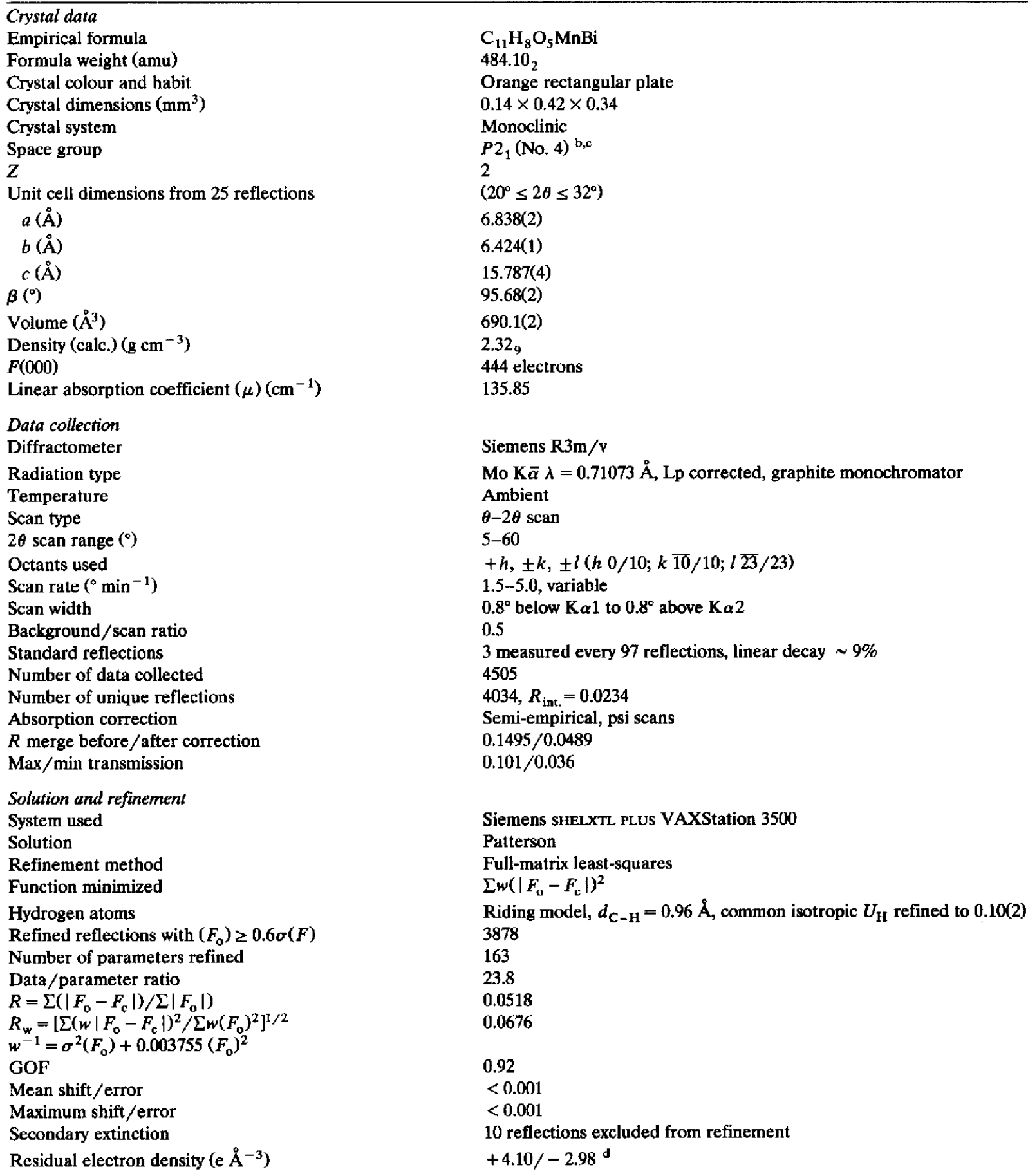

Siemens SHELXTL PLUS VAXStation 3500

Patterson

Full-matrix least-squares

$\sum w\left(\left|F_{\mathrm{o}}-F_{\mathrm{c}}\right|\right)^{2}$

Riding model, $d_{\mathrm{C}-\mathrm{H}}=0.96 \AA$, common isotropic $U_{\mathrm{H}}$ refined to $0.10(2)$

3878

163

23.8

0.0518

0.0676

0.92

$<0.001$

$<0.001$

10 reflections excluded from refinement

$+4.10 /-2.98$ d

anisotropically refined atoms are given in the form of the isotropic equivalent thermal parameter, $U_{\mathrm{eq}}$ defined as $1 / 3 \Sigma_{i} \Sigma_{j} U_{i j} a_{i}^{*} a_{j}^{*} a_{i} \cdot a_{j}{ }^{b}$ The other enantiomorph was checked with refinement leading to significantly higher residuals $\left(R=0.0756, R_{\mathrm{w}}=0.1058\right)$. ${ }^{\mathrm{c}}$ Systematic absences in the data gave centric $P 2_{1} / m$ (No. 11) and acentric $P 2_{1}$ (No. 4) as space group choices. Counting statistics strongly favoured an acentric distribution. However, since the presence of heavy atoms can modify these statistics, initial attempts were made to solve the structure in $P 2_{1} / m$. After no chemically reasonable solutions could be found in the centric space group, solution and refinement in $P 2_{1}$ proceeded smoothly without the problems typically associated with space group misassignment (severe correlations, unusual bond distances/angles, poor agreement of chemically equivalent bonds). ${ }^{d}$ All of the large residual electron density peaks/holes are associated with the $\mathrm{Bi}$ atom ( $<0.8 \AA$ from $\left.\mathrm{Bi}\right)$. There are no chemically significant peaks/holes in the final difference Fourier. 


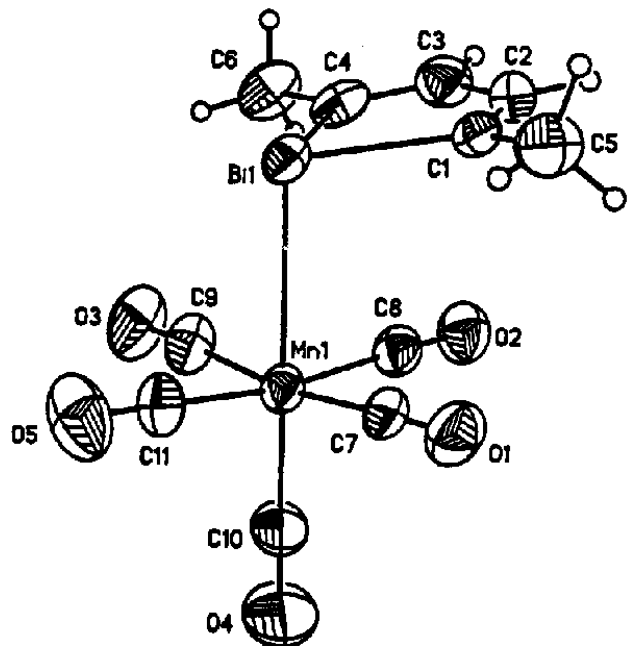

Fig. 1. ORTEP drawing ( $50 \%$ probability thermal ellipsoids) and labelling scheme for non-hydrogen atoms of 8 .

afforded 8 in $54 \%$ yield. Compound 8 forms orange crystals which are thermally stable up to the m.p. $124-125^{\circ} \mathrm{C}$. However, on melting, 8 rapidly loses $\mathrm{CO}$ to form $\pi$-complex 9.

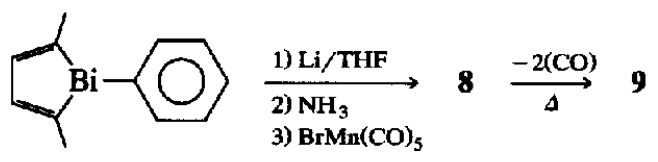

(10)

Crystals of 8 suitable for X-ray diffraction were obtained by recrystallization from acetone. Crystal data and data collection parameters are summarized in Table 1. An ORTEP drawing of the molecular structure of 8 showing the numbering scheme used in the refinement is illustrated in Fig. 1. Table 2 gives the positional values, while Table 3 gives the more important bond distances and angles. A table of observed and calculated structure factors is available from AJA on request.

The structure of 8 consists of a near planar 2,5-dimethylbismolyl moiety in which the pyramidal $\mathrm{Bi}$ atom is $\eta^{1}$-bonded to the $\mathrm{Mn}(\mathrm{CO})_{5}$ group. The geometry about $\mathrm{Mn}$ is that of a distorted octahedron with the equatorial carbonyl groups slightly oriented towards the bismuth atom. The Mn atom is 0.143(3) $\AA$ below the plane of the equatorial carbon atoms. Similar distortions are found for $\mathrm{Ph}_{2} \mathrm{BiMn}(\mathrm{CO})_{5}$ (11) [9] and indeed for many main group/transition metal carbonyl compounds.

The $\mathrm{Bi}, \mathrm{Mn}$, and the axial carbonyl carbon atom are collinear. The $\mathrm{Bi}-\mathrm{Mn}$ distance of $2.827(1) \AA$ is only slightly shorter than that of the more hindered $\mathrm{Ph}_{2} \mathrm{BiMn}(\mathrm{CO})_{5}(2.842(2) \AA$ ) [9] but considerably shorter
TABLE 2. Atomic coordinates and isotropic thermal parameters for 8

\begin{tabular}{lcrll}
\hline Atom & \multicolumn{1}{l}{$\boldsymbol{x}$} & \multicolumn{1}{l}{$\boldsymbol{y}$} & $\boldsymbol{z}$ & $\boldsymbol{u}_{\text {eq }}$ \\
\hline Bi1 & $\mathbf{0 . 0 0 4 8 9 ( 4 )}$ & 0.00000 & $0.19318(2)$ & $0.0429(1)$ \\
Mn1 & $0.1963(2)$ & $-0.1241(3)$ & $0.35202(9)$ & $0.0433(4)$ \\
O1 & $0.557(2)$ & $0.076(2)$ & $0.2950(8)$ & $0.067(3)$ \\
O2 & $0.299(1)$ & $-0.511(2)$ & $0.2635(6)$ & $0.071(3)$ \\
O3 & $-0.188(2)$ & $-0.305(2)$ & $0.3884(9)$ & $0.091(5)$ \\
O4 & $0.398(3)$ & $-0.255(3)$ & $0.5181(8)$ & $0.111(6)$ \\
O5 & $0.070(3)$ & $0.287(2)$ & $0.4171(9)$ & $0.097(6)$ \\
C1 & $0.238(1)$ & $-0.086(2)$ & $0.1076(6)$ & $0.050(3)$ \\
C2 & $0.193(2)$ & $-0.268(3)$ & $0.0738(8)$ & $0.060(4)$ \\
C3 & $0.026(2)$ & $-0.385(2)$ & $0.0922(8)$ & $0.062(4)$ \\
C4 & $-0.095(2)$ & $-0.317(2)$ & $0.1475(8)$ & $0.055(3)$ \\
C5 & $0.400(2)$ & $0.058(3)$ & $0.086(1)$ & $0.073(5)$ \\
C6 & $-0.274(2)$ & $-0.428(2)$ & $0.171(1)$ & $0.070(5)$ \\
C7 & $0.418(1)$ & $0.006(3)$ & $0.3151(6)$ & $0.048(2)$ \\
C8 & $0.256(2)$ & $-0.367(2)$ & $0.2956(7)$ & $0.052(3)$ \\
C9 & $-0.046(2)$ & $-0.239(2)$ & $0.3730(9)$ & $0.061(4)$ \\
C10 & $0.318(2)$ & $-0.204(2)$ & $0.4550(8)$ & $0.066(4)$ \\
C11 & $0.115(2)$ & $0.124(2)$ & $0.3920(8)$ & $0.057(4)$ \\
\hline
\end{tabular}

than the $\mathrm{Bi}-\mathrm{Mn}$ bond lengths of the very crowded $\mathrm{Bi}\left(\mathrm{Mn}(\mathrm{CO})_{5}\right)_{3}(2.88-2.92 \AA)[10]$.

The bond angles and lengths of the dimethylbismolyl moiety of 8 are identical to those found for 2,2',5,5'-tetramethylbibismole (12) [11]. However the $\mathrm{C}(1)-\mathrm{Bi}-\mathrm{Mn}$ and $\mathrm{C}(4)-\mathrm{Bi}-\mathrm{Mn}$ bond angles $\left(99.8^{\circ}\right.$,

TABLE 3. Selected bond distances $(\AA)$ and angles $\left({ }^{\circ}\right)$ for 8

\begin{tabular}{|c|c|c|c|}
\hline \multicolumn{4}{|l|}{ Bond lengths } \\
\hline Bi1-Mn1 & $2.827(1)$ & $\mathrm{O} 2-\mathrm{C} 8$ & $1.11(2)$ \\
\hline $\mathrm{Bi1}-\mathrm{C} 1$ & $2.26(1)$ & $\mathrm{O3}-\mathrm{Cg}$ & $1.10(2)$ \\
\hline $\mathrm{Bi1}-\mathrm{C} 4$ & $2.25(1)$ & $\mathrm{O} 4-\mathrm{C} 10$ & $1.14(2)$ \\
\hline $\mathrm{Mn} 1-\mathrm{C} 7$ & $1.87(1)$ & $\mathrm{O} 5-\mathrm{C} 11$ & $1.17(2)$ \\
\hline Mn1-C8 & $1.86(1)$ & $\mathrm{C} 1-\mathrm{C} 2$ & $1.31(2)$ \\
\hline Mn1-C9 & $1.87(1)$ & C1-C5 & $1.51(2)$ \\
\hline $\mathrm{Mn1-C10}$ & $1.82(1)$ & $\mathrm{C} 2-\mathrm{C} 3$ & $1.42(2)$ \\
\hline $\mathrm{Mn} 1-\mathrm{C} 11$ & $1.82(1)$ & $\mathrm{C} 3-\mathrm{C} 4$ & $1.33(2)$ \\
\hline $\mathrm{O} 1-\mathrm{C} 7$ & $1.12(2)$ & C4-C6 & $1.50(2)$ \\
\hline \multicolumn{4}{|l|}{ Bond angles } \\
\hline Bi1-Mn1-C7 & 85.1(3) & C1-Bi1-C4 & $78.2(4)$ \\
\hline Bi1-Mn1-C8 & $85.2(3)$ & $\mathrm{C} 1-\mathrm{C} 2-\mathrm{C} 3$ & $123(1)$ \\
\hline Bi1-Mn1-C9 & $86.0(4)$ & $\mathrm{C} 2-\mathrm{C} 1-\mathrm{C} 5$ & $127(1)$ \\
\hline Bi1-Mn1-C10 & $179.5(5)$ & $\mathrm{C} 2-\mathrm{C} 3-\mathrm{C} 4$ & $121(1)$ \\
\hline Bi1-Mn1-C11 & $86.1(4)$ & $\mathrm{C} 3-\mathrm{C} 4-\mathrm{C} 6$ & $126(1)$ \\
\hline $\mathrm{Bi1}-\mathrm{C} 1-\mathrm{C} 2$ & $108.1(8)$ & C7-Mn1-C8 & $90.2(6)$ \\
\hline $\mathrm{Bi} 1-\mathrm{Cl}-\mathrm{C} 5$ & $124.6(9)$ & $\mathrm{C} 7-\mathrm{Mn} 1-\mathrm{C} 9$ & $171.0(5)$ \\
\hline $\mathrm{Bi1}-\mathrm{C4}-\mathrm{C3}$ & $108.6(9)$ & C7-Mn1-C10 & $95.3(6)$ \\
\hline Bil-C4-C6 & $125.5(9)$ & C7-Mn1-C11 & $90.0(6)$ \\
\hline Mn1-Bí1-C1 & $99.8(3)$ & C8-Mn1-C9 & $89.6(6)$ \\
\hline Mn1-Bi1-C4 & 97.3(3) & $\mathrm{C} 8-\mathrm{Mn} 1-\mathrm{C} 10$ & $95.1(6)$ \\
\hline $\mathrm{Mn1}-\mathrm{C} 7-\mathrm{O} 1$ & $176(1)$ & $\mathrm{C} 8-\mathrm{Mn} 1-\mathrm{C} 11$ & $171.2(5)$ \\
\hline $\mathrm{Mn} 1-\mathrm{C}-\mathrm{O} 2$ & $177(1)$ & C9-Mn1-C10 & 93.6(7) \\
\hline $\mathrm{Mn1}-\mathrm{C} 9-\mathrm{O} 3$ & $177(1)$ & C9-Mn1-C11 & $88.9(6)$ \\
\hline Mn1-C10-O4 & $178(1)$ & C10-Mn1-C11 & $93.6(6)$ \\
\hline Mn1-C11-O5 & $178(1)$ & & \\
\hline
\end{tabular}


$\left.97.3^{\circ}\right)$ are significantly larger than the corresponding $\mathrm{C}-\mathrm{Bi}-\mathrm{Bi}$ bonds angles $\left(88.8^{\circ}, 90.0^{\circ}\right)$ of 12 . It seems likely that this increase in the angles at $\mathrm{Bi}$ is due to steric repulsion between the carbonyl and bismolyl groups. It might be noted that a similar increase in the $\mathrm{C}-\mathrm{Bi}$ metal bond angles occurs between $\mathrm{Ph}_{4} \mathrm{Bi}_{2}$ [12] and metal carbonyl complexes $\mathrm{Ph}_{2} \mathrm{BiMn}(\mathrm{CO})_{5}$ [9] and $\mathrm{Ph}_{2} \mathrm{BiCo}(\mathrm{CO})_{3} \mathrm{PPh}_{3}(13)$ [13].

That the bond angles about $\mathrm{Bi}$ are substantially smaller than tetrahedral suggests that the Bi lone pair is essentially $\mathbf{s}$ in character and consequently should have a low availability for bonding. This is consistent with the failure of 8 to form the hypothetical bismolyl bridged complex 14 on heating. The corresponding Asand P-bridged complexes $\mathbf{1 5}$ are formed from tetraphenyl derivatives of 7 [2].

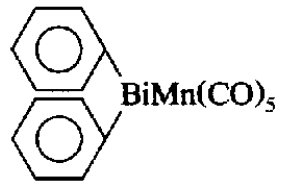

(11)

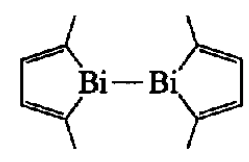

(12)

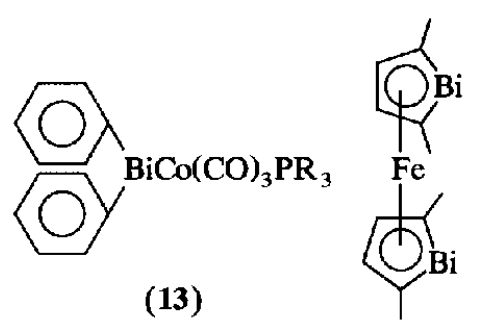

(16)

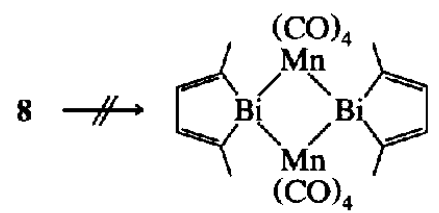

(14)

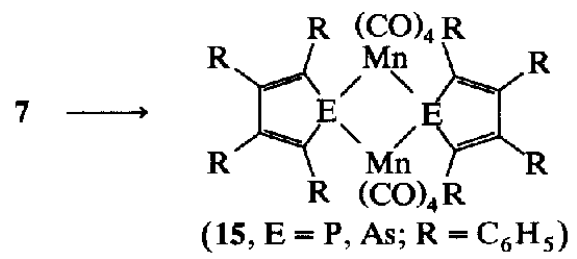

The availability of 8 allows a comparison of the IR spectra for the series of $\left(\eta^{1}\right.$-heteroyl) $\mathrm{Mn}(\mathrm{CO})_{5}$ complexes (Table 4). The $\nu(\mathrm{CO})$ values decrease in the sequence $\mathrm{P}>\mathrm{As}>\mathrm{Sb}>\mathrm{Bi}$. This trend differs from that observed for the usual dative bonded series $\left(\mathrm{R}_{3} \mathrm{E} \leftarrow \mathrm{M}\right)$, where the $\nu(\mathrm{CO})$ values change little with atomic number $[13,14]$. The decrease in the $\nu(\mathrm{CO})$ values in the covalently bonded series $\left(R_{2} E-M, 6\right)$ is
TABLE 4. The IR spectra of the complexes ( $\eta^{1}$-heterolyl)Mn(CO) in the carbonyl stretching region ${ }^{a}$

\begin{tabular}{llllll}
\hline Complex & $\nu(\mathrm{CO})\left(\mathrm{cm}^{-1}\right)$ & & Ref. \\
\hline $\mathrm{Mn}(\mathrm{CO})_{5}\left(\mathrm{PC}_{4} \mathrm{Ph}_{4}\right)$ & 2111 & 2032 & 2024 & 2002 & 2 \\
$\mathrm{Mn}(\mathrm{CO})_{5}\left(\mathrm{AsC}_{4} \mathrm{Ph}_{4}\right)$ & 2105 & 2026 & 2017 & 1999 & 2 \\
$\mathrm{Mn}(\mathrm{CO})_{5}\left(\mathrm{SbC}_{4} \mathrm{Ph}_{4}\right)$ & 2096 & 2016 & 2002 & 1992 & 2 \\
$\mathrm{Mn}(\mathrm{CO})_{5}\left(\mathrm{BiC}_{4} \mathrm{Me}_{2} \mathrm{H}_{2}\right)$ & $2085 \mathrm{~s}$ & & $2023 \mathrm{w}$ & $1995 \mathrm{~s}$ & This \\
& & & & & work \\
\hline
\end{tabular}

${ }^{a}$ All spectra recorded in hexane.

consistent with an increase in the donor character of the pnictogen atoms with increasing atomic number. However, this trend does not appear to be due to any particularity of the heterolyl ring systems since the $\nu(\mathrm{CO})$ values of 8 are nearly identical to those of 11 [9]. Indeed similar trends of decreases in $\nu(\mathrm{CO})$ values from lighter to heavier donor atoms have been observed for metal carbonyl complexes with Group 16 [15] and 17 ligands [16].

The crystals obtained for 9 were not of crystallographic quality. The assignment of the structure as $\left(\eta^{5}-\mathrm{C}_{6} \mathrm{H}_{8} \mathrm{Bi}\right) \mathrm{Mn}(\mathrm{CO})_{3}$ is based on spectroscopic data. Metal $\pi$-coordination of the dimethylbismacyclopentadienyl ring of 9 is indicated by the large upfield shift of the $\mathrm{CH}$-carbon ring signals relative to those of 8 in the ${ }^{13} \mathrm{C}$ NMR spectrum. Indeed both the ${ }^{1} \mathrm{H}$ and ${ }^{13} \mathrm{C}$ NMR spectra of 8 are very similar to those of $2,2^{\prime}, 5,5^{\prime}$-tetramethyl-1,1'-dibismaferrocene (16), the structure of which shows $\eta^{5}$-ring coordination [11].

A comparison of the IR spectra of the $\left(\eta^{5}\right.$ heterolyl)Mn(CO) ${ }_{3}$ complexes shows that the $\nu(\mathrm{CO})$ values decrease with $\mathrm{N}>\mathrm{P}>\mathrm{As}>\mathrm{Sb} \approx \mathrm{Bi}$ (Table 5). These data suggest that the heterolyl ligands become better $\pi$-donors to $\mathrm{Mn}(\mathrm{CO})_{3}$ as the heteroatoms increase in atomic number. A similar trend for the group 15 ( $\eta^{6}$-heterobenzene) $\mathrm{Mo}(\mathrm{CO})_{3}$ complexes [17] has been associated with the decreasing ionization potentials of the free ligands [18]. We suggest that the heavier heterocyclopentadienyl groups are good $\pi$ bases for the same reasons [19].

TABLE 5. The IR spectra of the complexes $\left(\eta^{5}\right.$-heterolyl)Mn(CO) in the carbonyl stretching region

\begin{tabular}{lllll}
\hline Complex & \multicolumn{2}{l}{$\nu(\mathrm{CO})\left(\mathrm{cm}^{-1}\right)$} & & Ref. \\
\hline $\mathrm{Mn}(\mathrm{CO})_{3}\left(\mathrm{NC}_{4} \mathrm{H}_{4}\right)$ & 2062 & 1980 & & $3 \mathrm{~b}$ \\
$\mathrm{Mn}(\mathrm{CO})_{3}\left(\mathrm{PC}_{4} \mathrm{H}_{2} \alpha-\mathrm{Ph}_{2}\right)^{\text {a }}$ & 2030 & 1961 & 1950 & $4 \mathrm{~d}$ \\
$\mathrm{Mn}(\mathrm{CO})_{3}\left(\mathrm{PC}_{4} \mathrm{H}_{2} \beta-\mathrm{Me}_{2}\right)^{\text {a }}$ & 2032 & 1958 & 1954 & $4 \mathrm{a}$ \\
$\mathrm{Mn}(\mathrm{CO})_{3}\left(\mathrm{AsC}_{4} \mathrm{H}_{2} \alpha-\mathrm{Me}_{2}\right)^{\mathrm{b}}$ & 2020 & 1948 & 1942 & $5 \mathrm{~b}$ \\
$\mathrm{Mn}(\mathrm{CO})_{3}\left(\mathrm{SbC}_{4} \mathrm{H}_{2} \alpha-\mathrm{Me}_{2}\right)^{\mathrm{c}}$ & $2010^{\text {e }}$ & $1948 \mathrm{br}$ & & 6 \\
$\mathrm{Mn}(\mathrm{CO})_{3}\left(\mathrm{BiC}_{4} \mathrm{H}_{2} \alpha-\mathrm{Me}_{2}\right)^{\text {d }}$ & $2011 \mathrm{~s}$ & $1942 \mathrm{~s}$ & $1937 \mathrm{~s}$ & This \\
& & & & work
\end{tabular}

a Solvent, decalin. ${ }^{\mathrm{b}}$ Solvent, hexadecane. ${ }^{\mathrm{c}}$ Solvent, cyclohexane.

${ }^{d}$ Solvent, hexane. ${ }^{e}$ Misquoted as $2100 \mathrm{~cm}^{-1}$ in ref. $5 \mathrm{~b}$. 


\section{Experimental details}

\subsection{General remarks}

All reactions were carried out under an atmosphere of nitrogen. Solvents were dried by using standard procedures. The mass spectra were determined by using a VG-70-S spectrometer, while the NMR spectra were obtained by using either a Brucker WH-360 or AM-300 spectrometer on solutions in $\mathrm{CDCl}_{3}$ or $\mathrm{C}_{6} \mathrm{D}_{6}$ as noted. The ${ }^{1} \mathrm{H}$ NMR and ${ }^{13} \mathrm{C}$ NMR spectra were calibrated using signals from the solvents referenced to $\mathrm{Me}_{4} \mathrm{Si}$. The IR spectra were recorded using a Nicolet 5DX spectrometer. The combustion analyses were determined by Galbraith Laboratory, Knoxville, TN.

\section{2. $\left(\eta^{1}-2,5\right.$-Dimethylbismolyl) $\mathrm{Mn}(\mathrm{CO})_{5}(8)$}

An excess $(0.5 \mathrm{~g})$ of lithium wire cut into small pieces was added to a solution of 1-phenyl-2,5-dimethylbismole $(1.0 \mathrm{~g}, 2.0 \mathrm{mmol})$ in $20 \mathrm{ml}$ of THF at $0^{\circ} \mathrm{C}$. The colour changed to green-brown and stirring was continued for $4 \mathrm{~h}$. The solution was filtered from the excess lithium and cooled at $-35^{\circ} \mathrm{C}$. Gaseous $\mathrm{NH}_{3}$ was bubbled through for $5 \mathrm{~min}$ and the reaction mixture was allowed to warm to $0^{\circ} \mathrm{C}$. Excess $\mathrm{NH}_{3}$ was removed by bubbling $\mathrm{N}_{2}$ through the solution and $10 \mathrm{ml}$ of THF was added. The solution was then cooled to $-78^{\circ} \mathrm{C}$ and cannulated into a suspension of $\mathrm{BrMn}(\mathrm{CO})_{5}(2 \mathrm{~g}$, $7.30 \mathrm{mmol}$ ) in $20 \mathrm{ml}$ of THF at $-78^{\circ} \mathrm{C}$. The brown solution was stirred at $-78^{\circ} \mathrm{C}$ for $4 \mathrm{~h}$ and then allowed to warm to $0^{\circ} \mathrm{C}$ for $1 \mathrm{~h}$. After removal of the solvent, the residue was extracted with $70 \mathrm{ml}$ of hexane. After filtration, the hexane extracts were orange. Cooling to $-15^{\circ} \mathrm{C}$ gave orange shiny needles which were recrystallized from acetone to give $0.70 \mathrm{~g}(54 \%)$ of 8 , m.p. $124-125^{\circ} \mathrm{C}$. Anal. Found: C, 22.29; H, 2.39. $\mathrm{C}_{11} \mathrm{H}_{8} \mathrm{Bi}-$ $\mathrm{MnO}_{5}$ calc.: C, 22.73; H, 2.54\%. ${ }^{1} \mathrm{H}$ NMR $\left(\mathrm{CDCl}_{3}\right): \delta$ $2.33(\mathrm{~s}, 6 \mathrm{H}) ; 8.16(\mathrm{~s}, 2 \mathrm{H}) .{ }^{13} \mathrm{C} \mathrm{NMR}\left(\mathrm{CDCl}_{3}\right): \delta 27.7$ $\left(\mathrm{CH}_{3}\right) ; 150.8(\mathrm{CH}) ; 166$ br (CBi); CO not observed. MS $m / e$ (intensity): $484\left(15, \mathrm{M}^{+}\right.$for $\left.\mathrm{C}_{11} \mathrm{H}_{8} \mathrm{BiMnO}_{5}\right) ; 344$ (100). MS exact mass (EI): Found: $483.9548 . \mathrm{C}_{11} \mathrm{H}_{8} \mathrm{Bi}-$ $\mathrm{MnO}_{5}$ calc.: 483.9556 .

\section{3. $\left(\eta^{5}-2,5-\right.$ Dimethylbismolyl) $\mathrm{Mn}(\mathrm{CO})_{3}(9)$}

$\left(\eta^{1}-2,5-\text { Dimethylbismolyl)Mn(CO) }\right)_{5}(99 \mathrm{mg}, 0.23$ $\mathrm{mmol}$ ) was heated to $125^{\circ} \mathrm{C}$ for $5 \mathrm{~h}$ affording a dark brown solid, which was taken up in hexane. The solution was filtered and solvent was removed to afford 80 mg $(90 \%)$ of 8 as black crystals, m.p. $78-80^{\circ} \mathrm{C} .{ }^{1} \mathrm{H}$ NMR $\left(\mathrm{C}_{6} \mathrm{D}_{6}\right): \delta 1.89(\mathrm{~s}, 6 \mathrm{H}) ; 8.32(\mathrm{~s}, 2 \mathrm{H}) .{ }^{13} \mathrm{C}$ NMR $\left(\mathrm{C}_{6} \mathrm{D}_{6}\right): \delta 26.7\left(\mathrm{CH}_{3}\right) ; 111.5(\mathrm{CH}) ; \mathrm{CBi}$ and $\mathrm{CO}$ not observed. MS (EI) $m / z$ (intensity): $428\left(40, \mathrm{M}^{+}\right.$for $\mathrm{C}_{9} \mathrm{H}_{8} \mathrm{BiMnO}_{3}$ ), 264 (100). MS exact mass: Found: 427.9653. $\mathrm{C}_{9} \mathrm{H}_{8} \mathrm{BiMnO}_{3}$ calc.: 427.9658 .

\section{Acknowledgements}

We are grateful to the Research Corporation, to NATO Scientific Affairs, and to the donors of the Petroleum Research Fund administered by The American Chemical Society for partial support of this work.

\section{References}

1 For a review of phospholyl complexes see: F. Mathey, Nouv. J. Chim., 11 (1987) 585.

2 E. W. Abel and C. Towers, J. Chem. Soc., Dalton Trans., (1979) 814.

3 (a) K. K. Joshi and P. L. Pauson, Proc. Chem. Soc., (1962) 326; (b) K. K. Joshi, P. L. Pauson, A. R. Qazi and W. H. Stubbs, J. Organomet. Chem., 1 (1964) 471.

4 (a) F. Mathey, Tetrahedron Lett., (1976) 4155; (b) F. Mathey and J.-P. Lampin, J. Organomet. Chem., 128 (1977) 297; (c) F. Mathey, A. Mitschler and R. Weiss, J. Am. Chem. Soc., 100 (1978) 5748; (d) A. Breque, F. Mathey and C. Santini, J. Organomet. Chem., 165 (1979) 129.

5 E. W. Abel, I. W. Nowell, A. G. J. Modinos and C. Towers, Chem. Commun., (1973) 258;

(b) G. Thiollet, R. Poilblanc, D. Voigt and F. Mathey, Inorg. Chim. Acta, 30 (1978) L294.

6 A. J. Ashe, III and T. R. Diephouse, J. Organomet. Chem., 202 (1980) C95.

7 N. C. Norman, Chem. Soc. Rev., 17 (1988) 269.

8 A. J. Ashe, III and F. J. Drone, Organometallics, 3 (1984) 495.

9 J. M. Cassidy and K. H. Whitmire, Inorg. Chem., 30 (1991) 2788.

10 J. M. Wallis, G. Müller and H. Schmidbaur, Inorg. Chem., 26 (1987) 458 .

11 A. J. Ashe, III, J. W. Kampf, D. B. Puranik and S. M. Al-Taweel, Organometallics, 11 (1992) 2743.

12 F. Calderazzo, A. Morvillo, G. Pelizzi and R. Poli, J. Chem. Soc., Chem. Commun., (1983) 507.

13 F. Calderazzo, R. Poli and G. Pelizzi, J. Chem. Soc., Dalton Trans., (1984) 2535.

14 D. Benlian and M. Bigorgne, Bull. Soc. Chim. Fr., (1963) 1583.

15 J. L. Atwood, I. Bernal, F. Calderazzo, L. G. Canada, R. Poli, R. D. Rogers, C. A. Veracini and D. Vitali, Inorg. Chem., 22 (1983) 1797.

16 H. D. Kaesz, R. Bau, D. Hendrickson and J. M. Smith, J. Am. Chem. Soc., 89 (1967) 2844.

17 (a) A. J. Ashe, III and J. C. Colburn, J. Am. Chem. Soc., 99 (1977) 8099; (b) J. C. Colburn, Ph.D. Thesis, University of Michigan, 1978.

18 (a) C. Batich, E. Heilbronner, V. Hornung, A. J. Ashe, III, D. T. Clark, U. T. Cobley, D. Kilcast and I. Scanlan, J. Am. Chem. Soc., 95 (1973) 928; (b) J. Bastide, E. Heilbronner, J. P. Maier and A. J. Ashe, III, Tetrahedron Lett., (1976) 411.

19 For a MO treatment of phosphacymantrene see: G. Guimon, G. Pfister-Guillouzo and F. Mathey, Nouv. J. Chim., 3 (1979) 725. 